\title{
Evaluation of Insecticidal Activities of Common Cocklebur Fruit Extract against Pulse Beetle Callosobruchus chinensis (Coleoptera: Bruchidae)
}

\author{
Balaram Roy, Shah Jalal, Bikash Chandra Sarker, Md Ruhul Amin ${ }^{1 *}$, Yong Ho Jeon ${ }^{2}$ and Ik-Jo Chun ${ }^{3}$ \\ Department of Agricultural Chemistry, Hajee Mohammad Danesh Science and Technology University, Dinajpur 5200, Bangladesh \\ ${ }^{1}$ Department of Entomology, Hajee Mohammad Danesh Science and Technology University, Dinajpur 5200, Bangladesh \\ ${ }^{2}$ Department of Bioresource Sciences, Andong National University, Andong 760-749, Korea \\ ${ }^{3}$ Department of Horticulture and Breeding, Andong National University, Andong 760-749, Korea

\section{팥바구미에 대한 도개마리 열매의 살충력 평가} \\ Balaram Roy · Shah Jalal · Bikash Chandra Sarker · Md Ruhul Amin ${ }^{1 *} \cdot$ 전용호 $^{2} \cdot$ 전익조 $^{3}$ \\ Department of Agricultural Chemistry, Hajee Mohammad Danesh Science and Technology University, Dinajpur 5200, Bangladesh \\ ${ }^{1}$ Department of Entomology, Hajee Mohammad Danesh Science and Technology University, Dinajpur 5200, Bangladesh \\ ${ }^{2}$ 안동대학교 생명자원과학부 식물의학전공, ${ }^{3}$ 안동대학교 원예학과
}

\begin{abstract}
In this study, 1, 2 and 4\% aqueous extracts of common cocklebur (Xanthium strumarium) fruit were tested against pulse beetle (Callosobruchus chinensis) for development of an environmental friendly control methods of this pest. The common cocklebur fruit extracts showed effects on mortality, repellency, fecundity and adult emergence of $\mathrm{C}$. chinensis and inhibited pulse grains from damage. The $4 \%$ extract showed the highest mortality (26\%) and repellency rate $(53.3 \%)$ at 2 day after treatment and 3 hours after treatment, respectively. The studied insects revealed lowest fecundity (113.7 female-1), highest percentage of adult emergence inhibition $(37.0 \%)$ and lowest percentage (42.3\%) of seed damage when they were reared on pulse grains mixed with $4 \%$ extract. This finding indicated that common cocklebur fruit extract may be used in the integrated management of pulse beetle for protecting stored grains.
\end{abstract}

Key words: Callosobruchus chinensis, Xanthium strumarium, mortality, repellency, fecundity

초 록: 화학합성 농약을 대체하기 위한 친환경 방제법 개발을 위해 $1,2,4 \%$ 의 도고마리 열매 수용성 추출물을 이용하여 팥바구미 살충력을 실험하 였다. 실험한 추출 농도에서 곤충 치사율, 기피성, 산란율과 성충 우화 및 팥의 피해 억제에 효과를 보여 주었다. $4 \%$ 의 추출물은 처리 후 2 일 후에 $26 \%$ 의 치사율과 처리 후 3 시간에 $53.3 \%$ 의 기피율을 각각 보였다. 또한 $4 \%$ 의 추출물을 팥과 섞었을 때 가장 낮은 산란율( $113.7 /$ 암컷)과, 성충 우 화율이 가장 많이 억제(37.0\%)되었고 종자 손상을 가장 적게(42.3\%) 받았다. 이러한 결과는 도고마리 추출물이 저장곡물을 팥바구미로부터 보호 하는 종합적 방제수단으로 사용될 수 있다.

검색어: 팥바구미, 도고마리, 치사율, 기피성, 산란율

A number of insect pests cause damage to pulses of which pulse beetle, Callosobruchus chinensis L. (Coleoptera: Bruchidae) is the most common pest throughout the world (Park et al., 2003). This cosmopolitan pest causes both quantitative and qualitative losses of pulses in stored and field condition (Hill,

*Comesponding author: ruhul_hstu@yahoo.com

Received January 21 2012; Revised July 242012

Accepted August 242012
1987). In the field, the female insects lay eggs on the green pods and after hatching the grubs feed on the pod cover and remain concealed inside the developing seeds. Whenever the infested seeds are stored then the pest population increase rapidly and results in total destruction within 3 to 4 months (Rahman and Talukder, 2006). Rustammni et al. (1985) reported that pulse beetle caused 56.3, 46.7, 44.1 and 50.9\% loses of black gram, mungbean, chick pea and garden pea, respectively in storage. Methyl bromide and phosphine as fumigants are commonly 
used to control this pest in storage but they have led to unintended side effects such as ozone depletion, environmental pollution, pest resistance, and toxicity on non-target organisms (Jembere et al., 1995; Okonkwo and Okoye, 1996). Therefore, development of alternative control is needed for management of stored grain pests.

Insect control utilizing botanical products are being used in many countries because botanicals are promising sources of pest control compounds and show insecticidal activity against stored product insect pests (Kim et al., 2003; Sim et al., 2006). Plant species are rich in bitter substances and showed toxic, repellent, antifeedant, growth and progeny inhibition activity against insect (Baytop, 1999). Roy et al. (2005) reported that petroleum ether extract of shiyalmutra (Blumea lacera) leaf possessed mortality and repellency activity against lesser grain borer and rice weevil. Plant materials show toxicity effects against insect species due to their complex mixtures of monoterpenoids and related phenols (Isman, 2000; Cetin and Yanikoglu, 2006; Kordali et al., 2008). Many plant products have been tested against pulse beetle but no similar work has been carried out with common cocklebur fruit extract. Therefore, an attempt was made to explore the insecticidal properties of common cocklebur fruit extract against $C$. chinensis.

\section{Material and Methods}

\section{Preparation of extract}

Common cocklebur, Xanthium strumarium L. (Asterales: Asteraceae) fruits were collected from the road side of Hajee Mohammad Danesh Science and Technology University (HSTU), Dinajpur, Bangladesh. The fruits were washed with tap water and dried in sunlight. Therefore, the fruits were dried in an oven at $50-60^{\circ} \mathrm{C}$ for $24 \mathrm{hrs}$ to gain constant weight. The dried fruits were ground with the help of a grinder. $10 \mathrm{~g}$ powder was taken in $2.5 \mathrm{~L}$ reagent bottle and $1000 \mathrm{ml}$ distilled water was added to it. Then the reagent bottle was put on a machine and allowed to shaking for $72 \mathrm{hrs}$. Therefore, the filtrate was considered as $1 \%$ concentration of common cocklebur fruit extract. Similar way 2, 3 and 4\% extracts were prepared and stored in a refrigerator until use.

\section{Mass rearing of insect}

C. chinensis were reared on black gram pulses (Vigna mungo) in the Entomology Laboratory of HSTU at $27 \pm 2{ }^{\circ} \mathrm{C}$ and $80 \pm 5 \%$ RH. Ten pair of 1-3 day old adult beetles was placed in glass jar containing black gram as food. The jar was fastened with net and the beetles were allowed for free mating and oviposition for a period of 7 days. Then the beetles were removed and the eggs in the pulses were allowed for hatching. Rearing was being continued until 3rd generations which were used for experimental purposes.

\section{Mortality test}

For this purpose adult insects were chilled for a period of 10 minutes. By using a micro pipette $1 \mathrm{ml}$ of 1,2 or $4 \%$ extract was applied to the dorsal thorax of the immobilized insects. A control treatment was made with distilled water. Ten insects per replication were treated. The insects were then transferred into $9 \mathrm{~cm}$ diameter Petri dishes containing food. Insect mortality rate was recorded after 1, 2, 3 and 4 days after treatment (DAT). All the trials were repeated five times and \% mortality was calculated.

\section{Repellency test}

Black gram grains were treated separately with 1, 2, 3 and $4 \%$ concentrations of plant extract and the grains were air dried. In each Petri dish treated and untreated grains were kept separately. Five pair of beetles was released at the centre of each Petri dish and a cover was placed on it. There were three replications for each concentration. The insects present on each portion were counted at hourly intervals up to fifth hour. The data were expressed as percentage repulsion (PR \%) by the formula, $\mathrm{PR}(\%)=(\mathrm{Nc}-50) \times 2$. Where, $\mathrm{Nc}=$ The percentage of insects present in the control half.

\section{Fecundity test}

Extract concentrations were mixed separately with black gram grains and the grains were air dried. Treated grains were put in different Petri dishes and five pair of newly emerged 
beetles was released in each Petri dish. A control treatment was made with untreated grain. There were three replications for each treatment. The fecundity was recorded after 7 days of the release of beetles. The eggs laid on black gram seeds in the Petri dish were counted by using hand lens.

\section{Effect on adult emergence and grain damage}

Different extract mixed grains were air dried and put separately in Petri dishes. A control treatment was made with untreated grain. Five pair of newly emerged beetles was released in each Petri dish. There were three replications for each treatment. After one week the adult beetles were removed. As the pulse beetle started to emerge after 30 days of egg laid, therefore, newly emerged beetles were counted and removed from the Petri dishes daily and continued 10 days. The adult inhibition rate $(\% \mathrm{IR})$ was calculated by using the formula, $\% \mathrm{IR}=(\mathrm{Cn}-\mathrm{Tn})$ $\times 100 / \mathrm{Cn}$. Where, $\mathrm{C}_{\mathrm{n}}=$ number of insects in control Petri dish, $\mathrm{T}_{\mathrm{n}}=$ number of insects in treated Petri dish. On completion of adult emergence counting, grains were taken out from the Petri dishes. Grains containing hole(s) were considered as damaged and the number of damaged grains for each treatment and replication were recorded.

\section{Statistical analysis}

Data were analyzed by analysis of variance (ANOVA) and the mean values were separated by Duncan Multiple Range Test (DMRT). All analyses were performed using SPSS (PASW statistics 18).

\section{Results and Discussion}

Mortality effect of common cocklebur fruit extracts on pulse beetle at different DAT is presented in Table 1. All the treatments showed significantly higher mortality compared to control (DMRT, $\mathrm{p} \leq 0.05$ ), and mortality increased with increasing dosages. Among the treatments, 4\% extract revealed the highest mortality rate (26\%) at 2 DAT. Amin et al. (2000) studied the toxicity effect of biskatali, neem and akanda leaf extract on lesser grain borer and reported that $4 \%$ biskatali extract exerted strong toxicity effect $(80.11 \%)$. They also reported that extract toxicity increased with increasing concentration. Another study report showed that 5\% Chenopodium ambroisoides plant extract at 5 day after treatment caused $54 \%$ mortality of C. maculates (Kemabonta and Okogbue, 2002).

The repellency effect of common cocklebur fruit extracts at different hours after treatment (HAT) is represented in Table 2.

Table 1. Effect of different concentrations of blood leaf plant extract on mortality of $C$. chinensis

\begin{tabular}{lcccr}
\hline \multirow{2}{*}{ Treatments } & \multicolumn{4}{c}{ \%Cumulative mortality } \\
\cline { 2 - 5 } Control & 1 DAT & 2 DAT & 3 DAT & 4 DAT \\
$1 \%$ extract & $2 \mathrm{~b}^{*}$ & $4 \mathrm{~b}$ & $6 \mathrm{~b}$ & $6 \mathrm{~b}$ \\
$2 \%$ extract & $12 \mathrm{a}$ & $26 \mathrm{ab}$ & $36 \mathrm{ab}$ & $42 \mathrm{ab}$ \\
$4 \%$ extract & $14 \mathrm{a}$ & $32 \mathrm{ab}$ & $42 \mathrm{ab}$ & $48 \mathrm{ab}$ \\
\hline
\end{tabular}

*Means within a column followed by no common letter(s) are significantly different (DMRT, $p \leq 0.05)$.

Table 2. Effect of different concentrations of blood leaf plant extract on repellency of $C$. chinensis

\begin{tabular}{cccccc}
\hline \multirow{2}{*}{ Treatments } & \multicolumn{5}{c}{ \%Repellency } \\
\cline { 2 - 6 } & 1 HAT & 2HAT & 3 HAT & 4HAT & 5HAT \\
\hline 1\% extract & $35.3 \mathrm{a}^{*}$ & $26.7 \mathrm{ab}$ & $33.3 \mathrm{~b}$ & $33.3 \mathrm{ab}$ & $26.7 \mathrm{~b}$ \\
$2 \%$ extract & $35.7 \mathrm{a}$ & $26.7 \mathrm{ab}$ & $40.0 \mathrm{ab}$ & $40.0 \mathrm{ab}$ & $40.0 \mathrm{a}$ \\
$4 \%$ extract & $35.7 \mathrm{a}$ & $33.3 \mathrm{a}$ & $53.3 \mathrm{a}$ & $46.7 \mathrm{a}$ & $46.7 \mathrm{a}$ \\
\hline
\end{tabular}

*Means within a column followed by no common letter(s) are significantly different (DMRT, $\mathrm{p} \leq 0.05)$. 
Results indicated that common cocklebur fruit extract showed significantly higher repellency compared to control (DMRT, $p$ $\leq 0.05)$ at 2, 3, 4 and 5 HAT and repellency increased with increasing dosages of extract. Among the extract concentrations, $4 \%$ exerted the highest repellency rate $(53.3 \%)$ at 3 HAT. Shahjahan and Amin (2000) studied the repellency effect of biskatali, neem and akanda plant extract on rice weevil and reported that $4 \%$ neem extract revealed the highest repellency effect (73.6\%) followed by biskatali (68.0\%) and akanda (58\%). Rahman et al. (2006) assessed 1, 2 and 4\% melgota fruit extract effect on rice weevil and found 9.84, 12.76 and $22.43 \%$ repellency, respectively.

Fig. 1 shows the effect of different concentrations of common cocklebur fruit extract on the fecundity of $C$. chinensis. Results showed significant differences (DMRT, $\mathrm{p} \leq 0.05$ ) and the beetles were reared on pulse grains mixed with $4 \%$ extract laid lowest number of eggs (113.7) followed by $2 \%$ (140.0), $1 \%$ (158.7) and control (185.0). Pulse beetle (C. maculates) showed

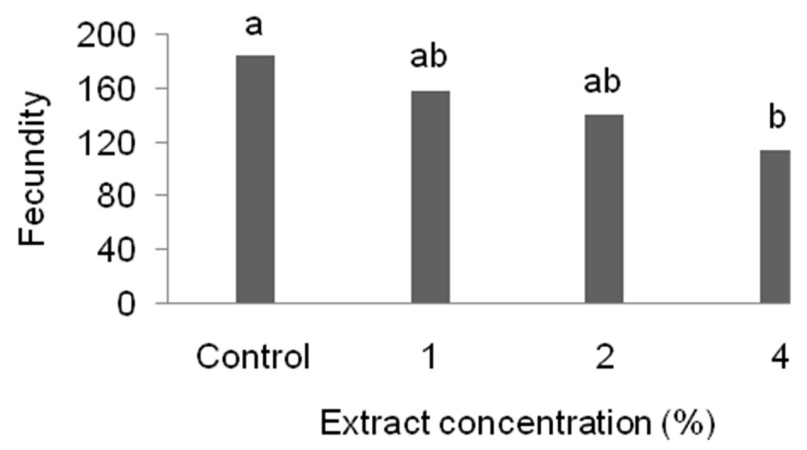

Fig. 1. Effect of different concentrations of blood leaf plant extract on fecundity of $C$. chinensis. Bars with no common letter(s) are significantly different (DMRT, $\mathrm{p} \leq 0.05$ ).

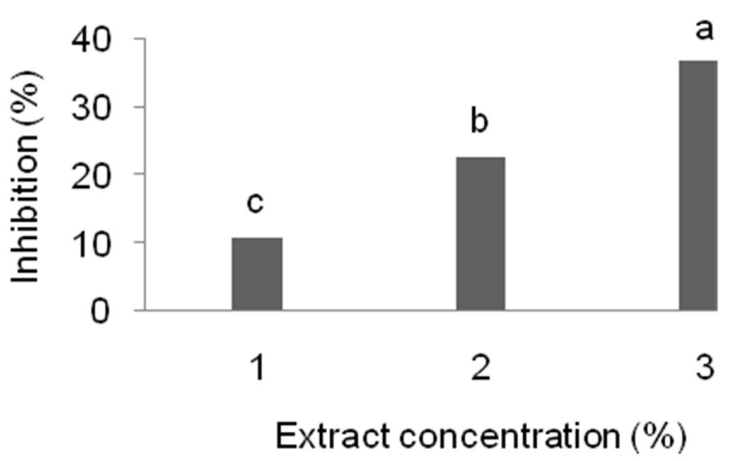

Fig. 2. Effect of different concentrations of blood leaf plant extract on adult emergence inhibition of $C$. chinensis. Bars with no common letter(s) are significantly different (DMRT, $\mathrm{p} \leq 0.05$ ). similar fecundity in the laboratory when the insects were reared on $1 \%$ nimbicidin treated gram seeds (Nandi et al., 2004). Capparis decidua stem and flower extracts also showed oviposition inhibitory effect against $C$. chinensis (Upadhyay et al., 2006).

Different concentrations of common cocklebur fruit extract showed significant effect (DMRT, $\mathrm{p} \leq 0.05$ ) on adult emergence inhibition of C. chinensis (Fig. 2). Pulse grains treated with $4 \%$ extract showed highest percentage of adult emergence inhibition $(37.0 \%)$ followed by 2 and $1 \%$. The effects of plant materials on the progeny inhibition of stored grain pests have reported by Amin el al. (2000) who observed that wheat grains mixed with $4 \%$ akanda, biskatali and neem leaf dusts had strong progeny inhibition (50.1, 56.7 and $56.0 \%$, respectively) on lesser grain borer.

Fig. 3 presented that lowest percentage of seed damage $(42.3 \%)$ was found at $4 \%$ concentration of blood leaf plant extract, whereas the highest rate $(91.0 \%)$ was found in control, and the results showed significant differences (DMRT, $\mathrm{p} \leq$ $0.05)$. Bitter gourd, small bitter gourd, bottle gourd and ridge gourd vegetable seed oil at $6-8 \mathrm{ml} \mathrm{kg-1}$ were found effective for protection of legume-pulse grains from $C$. chinensis infestation until 60 days of storage at laboratory condition (Mishra et al., 2006).

Plant materials possessed some chemicals viz. azadirachtin, azdirol, cymarin, digitoxin, kulactone, limocinin, salanin, toosendanin, xanthotoxin, etc. These chemicals are toxic and interrupt insect life and behavior. It was noted that water extract of plant materials manifest mortality, repellency and residual

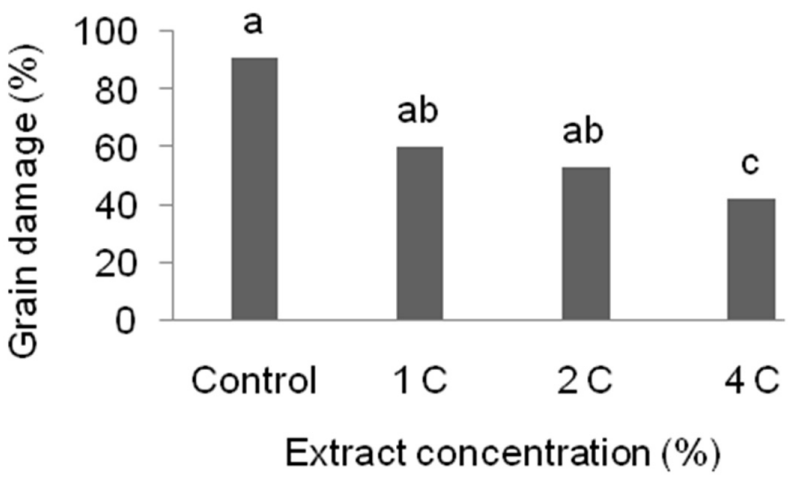

Fig. 3. Effect of different concentrations of blood leaf plant extract on grain damage of $C$. chinensis. Bars with no common letter(s) are significantly different (DMRT, $\mathrm{p} \leq 0.05$ ). 
toxicity effect against stored grain pests (Roy et al., 2010). Our results suggest that commom cocklebur fruit extracts have promising potential as an effective insecticide against pulse beetle. This fruit may have some toxic chemicals. Therefore, further studies are needed for chemical investigation to identify the compounds, and also potency and stability of the compounds for practical application against C. chinensis. Moreover, investigations are needed on human toxicity and fitness for consumption by humans and farm animals.

\section{Literature Cited}

Amin, M.R., Shahjahan, M., El-Taj, H.F., Iqbal, T.M.T., Hossain, M.A., 2000. Use of akanda, biskatali and neem leaves as botanical insecticides against lesser grain borer. Bangladesh J. Entomol. 10(1/2): 1-13.

Baytop, T., 1999. Therapy with medicinal plants in Turkey: today and in future. Istanbul University Press, Istanbul. pp. 166-167.

Cetin, H. and A. Yanikoglu. 2006. A study of the larvicidal activity of Origanum (Labiatae) species from southwest Turkey. J. Vector Ecol. 31(1), 118-122.

Hill, D.S., 1987. Agricultural insect of the tropics and their control. Second Edition, Cambridge University Press. Cambridge. p.746. Isman, M.B., 2000. Plant essential oils for pest and disease management. Crop Protec. 19 (8-10), 603-608.

Jembere, B., Obeng-Ofori, D., Hassanali, A., Nyamasyo, G.N.N., 1995. Products derived from the leaves of Ocimum kilimanndscharicum (Labiatae) as post-harvest grain protectant against the infestation of three major stored product insect pests. Bull. Entomol. Res. 85, 361-367.

Kemabonta, K.A., Okogbue, F., 2002. Chenopodium ambroisoides (Chenopodiaceae) as a grain protectant for the control of the cowpea pest, Callosobruchus maculatus (Coleoptera: Bruchidae). J. Fruit Ornam. Plant Res.10, 165-171.

Kim, S.I., Park, C., Ohh, M.H., Cho, H.C., Ahn, Y.J., 2003. Contact and fumigant activities of aromatic plant extracts and essential oils against Lasioderma serricorne (Coleoptera: Anobiidae). J. Stored Product Res. 39(1), 11-19.

Kordali, S., Cakir, A., Ozer, H., Cakmakci, R., Kesdek, K., Mete, E., 2008. Antifungal, phytotoxic and insecticidal properties of essential oil isolated from Turkish Origanum acutidens and its three components, carvacrol, thymol and $p$-cymene. Biores. Technol. 99(18), 8788-8795.
Mishra, D., Shukla, A.K., Tripathi, K.K., Singh, A., Dixit, A.K., Singh, K., 2006. Efficacy of application of vegetable seed oils as grain protectant against infestation by Callosobruchus chinensis and its effect on milling fractions and apparent degree of dehusking of legume-pulses. J. Oleo Sci. 56(1), 1-7.

Nandi, S., Howlader, M.T.H., Hossain, M.Z., Haque, M.A., 2004. Bioefficacy of nimbicidine against pulse beetle, Callosobruchus maculatus (F.) on stored gram. Bangladesh J. Zool. 36(2), 280-285.

Okonkwo, E.U., Okoye, W.I., 1996. The efficacy of four seed powders and the essential oils as protectants of cow-pea and maize grain against infestation by Callosobruchus maculatus (Fabricius) (Coleoptera: Bruchidae) and Sitophilus zeamais (Motschulsky) (Coleoptera: Curculionidae) in Nigeria. Intl. J. Pest Manag. 42, 143-146.

Park, I., Lee, S., Choi, D., Park, J., Ahn, Y., 2003. Insecticidal activities of constituents identified in the essential oil from the leaves of Chamaecyparis obtuse against Callosobruchus chinensis L. and Sitophilus oryzae (L). J. Stored Product Res. 39(4), 375-384.

Rahman, S.S., Talukder, F.A., 2006. Bioefficacy of some plant derivatives that protect the grain against pulse beetle, Callosobruchus maculatus. J. Insect Sci. 6, 19-25.

Rahman, S.S., Rahman, M.M., Khan, M.M.R., Begum, S.A., Roy, B., Shahed, F., 2006. Ethanolic extract of melgota, Macaranga postulata used for repellency, and insecticidal activity against rice weevil (Sitophilus oryzae). African J. Biotechnol. 6(4), 379-383.

Roy, B., Amin, M.R., Uddin, M.N., Islam, A.T.M.S., Islam, M.J., Halder, B.C. 2005. Leaf extracts of shiyalmutra (Blumea lacera Dc.) as botanical insecticides against lesser grain borer and rice weevil. J. Biol. Sci. 5(2), 201-204.

Roy, B., Sarker, B.C., Amin, M.R., Roy, B.C., Jalal, S., 2010. Bioefficacy of shiyalmutra leaf extract against rice weevil. J. Sci. Technol. (Dinajpur). 8, 1-5.

Rustammni, M.A., Naqvi, S.M.S.H., Munchi, G.H., Abrol, G.H., 1985. Relative resistance/susceptibility of different pulses against pulse beetle Callosobruchus chinensis L. Bangladesh J. Entomol. 6, 13-21.

Shahjahan, M., Amin, M.R., 2000. Evaluation of some plant extracts against rice weevil, Sitophilus oryzae L. J. Asiat. Soc. Bangladesh Sci. 26, 213-222.

Sim, M.J., Choi, D.R., Ahn, Y.J., 2006. Vapor phase toxicity of plant essential oils to Cadra cautella (Lepidoptera: Pyralidae). J. Econ. Entomol. 99(2), 593-598.

Upadhyay, R.K., Rohatgi, L., Chaubey, M.K., Jain, S.C., 2006. Ovipositional responses of the pulse beetle, Bruchus chinensis, Coleoptera: Bruchidae to extracts and compounds of Capparis decidua. J. Agric. Food Chem. 54(26), 9747-9751. 